\title{
Changes in heavy metal extractability from contaminated soils remediated with organic
} waste or biochar

\author{
A. Venegas, A. Rigol, M. Vidal* \\ Departament de Química Analítica, Universitat de Barcelona, Martí i Franquès 1-11, 08028- \\ Barcelona (Spain) \\ *Corresponding author: $\quad$ Telephone: (+34) 93403 9276; Fax: (+34) 934021233 \\ E-mail address: miquel.vidal@ub.edu (M. Vidal)
}

\begin{abstract}
The effect of the addition of organic waste or biochar on the extractability of heavy metals $(\mathrm{Cd}, \mathrm{Cu}, \mathrm{Ni}, \mathrm{Pb}$ and $\mathrm{Zn})$ was assessed in five heavy metal-contaminated soils. The amendments studied were: municipal organic waste compost (MOW), green waste (GW), biochar derived from tree bark (BF) and biochar derived from vine shoots (BS). The amendments were added to the soil at $10 \%$ dose. $\mathrm{A} \mathrm{pH}_{\text {stat }}$ leaching test was applied to the soils and soil+amendment mixtures to assess the effects of the amendments on the extractable metal concentration at the initial $\mathrm{pH}$ and in the $2-12 \mathrm{pH}$ range. MOW increased the DOC content in the mixtures for most soils, whereas the rest of amendments only increased the DOC content for the soil with the lowest DOC value. Moreover, in the mixtures obtained from soils with a low buffering capacity, the amendments increased $\mathrm{pH}$ (up to 3 units) and the acid neutralization capacity, thus decreasing the extractability of heavy metals at the initial $\mathrm{pH}$ of the mixtures. In a few cases, the amendments further decreased the concentrations of extractable metal due to an increase in the sorption capacity of the mixture, even though the soil had high initial $\mathrm{pH}$ and ANC values. MOW and GW generally led to larger decreases in metal extractability in the resulting mixtures than biochar, due to their higher sorption and acid neutralization capacities.
\end{abstract}

Keywords: immobilisation, soil, metal, organic amendments, remediation. 


\section{Introduction}

Soils are one of the major sinks for heavy metals released into the environment by anthropogenic activities. Unlike other contaminants, they do not generally undergo microbial or chemical degradation, and they persist in soils for a long time after their incorporation (Adriano, 2001). Regulations regarding the management of presumably metal contaminated soils are generally based on metal total concentration, but this information is usually not sufficient to assess the derived risk. Thus, information about metal interaction in soils and related mobility is required for decision making related to the management of contaminated soils and the selection of suitable remediation strategies.

Soil remediation techniques are often aimed at decreasing the mobility and bioavailability of heavy metals in soils, by modifying their interaction mechanisms (Park et al., 2011). In this context, chemical immobilisation via the addition of amendments is an appealing option for diminishing the mobility of heavy metals in the resulting soil+amendment mixtures (Kumpiene et al., 2008). This approach is less disruptive to the soil and ecosystem than other remediation strategies and is usually less expensive when waste materials are employed (Lombi et al., 2002). The main factors governing the efficacy of the addition of an amendment to a contaminated soil are the effect on the soil $\mathrm{pH}$, given the strong dependence of metal sorption mechanisms on this parameter, and the enhancement of specific metalamendment interactions that diminish the availability of heavy metals through sorption processes (Dijkstra et al., 2004). In this context, diverse amendments derived from biomass of natural origin (e.g. animal manure, compost and biochar) have been tested in remediation strategies, although differing conclusions about their efficiency have been reported (Clemente et al., 2007; Nwachukwu and Pulford, 2009; Beesley et al., 2010). For example, Beesley et al. (2010) assessed the effect of biochar and green-waste compost on the pore water concentration of $\mathrm{Cd}, \mathrm{Zn}$ and $\mathrm{Cu}$ in a mildly acidic soil. The copper concentration in soil solution increased following the addition of amendments, due to an increase in the DOC 
content, whereas $\mathrm{Cd}$ and $\mathrm{Zn}$ concentrations decreased, due to an increase in $\mathrm{pH}$ of the resulting soil mixture. Clemente et al. (2007) reported that cow manure had no effect on metal extractability, while an olive husk-derived amendment increased metal availability. The authors attributed this detrimental trend to the reduction in Mn oxides due to the degradation of phenolic compounds.

The effect of the addition of amendments to contaminated soils on metal availability should be tested first at the laboratory level, in order to avoid expensive experimental work at the field level, to better monitor changes in metal availability and to control the variables affecting the efficiency of the candidate amendments. In this context, the $\mathrm{pH}_{\text {stat }}$ leaching test has proven to be a valuable tool in the assessment of the available fraction of heavy metals in contaminated soils and in soil+amendment mixtures (Van der Sloot, 1990; Van der Sloot et al., 1996; Rigol et al., 2009; González-Núñez et al., 2012). This approach is appropriate for evaluating the dependence of contaminant release as a function of $\mathrm{pH}$ over a broad range of $\mathrm{pH}$ values, providing a complete assessment of metal availability in a given $\mathrm{pH}$ scenario (Kosson et al., 2002; Cappuyns and Swennen, 2008).

The aim of this work was to evaluate the ability of four organic amendments to reduce heavy metal mobility, here estimated using a leaching test, in five soils contaminated with $\mathrm{Cd}, \mathrm{Cu}$, $\mathrm{Ni}, \mathrm{Pb}$ and $\mathrm{Zn}$. The amendments were selected based on previous complete physicochemical characterisation and sorption assays carried out at the laboratory level (Venegas et al., 2015). $\mathrm{pH}_{\text {stat }}$ leaching tests were applied to the soil and soil+amendment samples within a broad $\mathrm{pH}$ range, and the acid neutralisation capacity in both untreated soils and soil+amendment mixtures was also determined to evaluate the effect of each amendment on the buffering capacity of the resulting mixtures. Comparison of the metal extractability curves obtained in the untreated soil and soil+amendment mixtures allowed assessment of the ability of the amendments to enhance heavy metal immobilisation depending on changes in $\mathrm{pH}$. 


\section{Materials and methods}

\subsection{Samples}

Five contaminated soils and four amendments of organic origin were used in this study. The contaminated soils were two agricultural soils originated from an area in the South of Spain affected by an accidental spill caused by a close mine exploitation (Aznalcóllar, Seville), thus being affected by pyritic sludge particles and acidic waste waters (RIB and QUE); a soil affected by mining activities (S15), also from the South of Spain; and two soils (ASCO and TENF) contaminated at laboratory level with a slightly acidic solution that contained $\mathrm{Cd}, \mathrm{Cu}$, $\mathrm{Ni}, \mathrm{Pb}$ and $\mathrm{Zn}$, and subsequently subjected to drying-wetting cycles to enhance the incorporation of the heavy metals and better simulate a real scenario. The drying-wetting cycles involved rewetting the samples at $100 \%$ of their field capacity and maintaining them in capped vessels at $40^{\circ} \mathrm{C}$ for $24 \mathrm{~h}$. Later, the samples were dried in open vessels at $40^{\circ} \mathrm{C}$ for 48 h. This procedure was repeated three times.

The amendments included a compost derived from collected municipal organic waste (MOW), which was initially processed in wet treatment tanks and then anaerobically fermented generating slurry that was subjected to composting; a compost from green waste (GW) originated from vegetable and plant residues, also containing soil material; a biochar derived from tree bark (BF) and a biochar derived from vine shoots (BS), both produced by pyrolysis at $400^{\circ} \mathrm{C}$ for $3 \mathrm{~h}$. All samples were dried, sieved through a $2 \mathrm{~mm}$ mesh, homogenized and stored in bottles before analysis.

\subsection{Soil+amendment mixtures}

The soil+amendment mixtures were prepared at 10\% w/w amendment dose: $30 \mathrm{~g}$ of amendment were homogeneously mixed with $270 \mathrm{~g}$ of soil. This dose represents a high application rate, probably difficult to be applied at field level, but within the dose ranges reported in previous works to test the efficacy of amendments at laboratory level (Beesley et 
al., 2010; Houben et al., 2013). The mixtures were subjected to three drying-wetting cycles, in order to simulate field conditions. The mixtures were subsequently mixed in an end-over-end shaker for two days and stored in bottles before analysis.

\subsection{Soil characterisation}

The amendments had previously been fully characterised in terms of physicochemical parameters such as $\mathrm{pH}$, cation exchange capacity (CEC), acid neutralisation capacity (ANC), dissolved organic carbon (DOC), total organic carbon (TOC), and organic matter content in extracts obtained according to the protocols for fulvic and humic acid determination. A detailed description of the amendment characteristics is presented in Venegas et al. (2015). Regarding soil characterisation, the $\mathrm{pH}$ of the soil samples was measured in Milli-Q water, using a solution-to-soil ratio of 1:2.5 $\mathrm{mL} \mathrm{g}^{-1}$. The organic matter content was determined by the loss of weight on ignition (LOI) at $450^{\circ} \mathrm{C}$ for $16 \mathrm{~h}$ of $3 \mathrm{~g}$ of soil sample previously ovendried overnight at $110^{\circ} \mathrm{C}$ (Burt, 2004). CEC was determined after extraction with ammonium acetate (Bower et al., 1952) (see Supplementary Material for further details). The dissolved organic carbon (DOC) in the extracts was determined using a total organic carbon analyser (TOC-50000, Shimatzu). For the determination of DOC in those extracts obtained by addition of acid, it was necessary to carry out experiments in parallel substituting $\mathrm{HNO}_{3}$ with $\mathrm{HCl}$. The particle size distribution was determined by the pipette method, based on the varying settling velocity in a fluid medium according to particle size (Burt, 2004). The carbonate content was determined using the calcimeter Bernard method (Mueller and Gastner, 1971). Field capacity (FC) was determined by wetting the samples until a saturated paste was obtained, and then centrifuging them at $0.33 \mathrm{bar}(75 \mathrm{x} g$ for $30 \mathrm{~min})$. Later, the samples were dried at $105^{\circ} \mathrm{C}$ to constant weight and FC was derived from the weight lost.

The total content of trace elements in soil samples was determined by soil digestion in a closed microwave digestion system (Milestone Ethos Touch Control) following an adaptation 
of the EPA3052 method (USEPA, 2008). Trace elements were determined in the resulting solutions by ICP-OES and ICP-MS. Details can be found in the Supplementary Material.

\subsection{Acid neutralization capacity}

The neutralization capacity of the samples was examined by the CEN/TS $15364 \mathrm{pH}$ titration test (CEN/TS, 2006a). To obtain the titration curve, first the initial $\mathrm{pH}$ of each sample was measured in a 1:100 sample mass/volume of deionized water (2 $\mathrm{g}$ of soil: $200 \mathrm{~mL}$ of water). Next, consecutive volumes of $200 \mu \mathrm{L}$ of $0.3-1 \mathrm{~mol} \mathrm{~L}^{-1} \mathrm{HNO}_{3}$ or $0.5-1 \mathrm{~mol} \mathrm{~L}^{-1} \mathrm{NaOH}$ were added, and the suspension was stirred. The resulting $\mathrm{pH}$ of the suspension was measured 3040 min after the addition of either acid or base. The acid and base additions were repeated to achieve $\mathrm{pH}$ values in the range between 2 and 12. $\mathrm{pH}$ titration curves of soil and soil+amendment mixtures were obtained in triplicate. The titration curves permitted the quantification of the acid neutralization capacity (ANC) of the untreated soils and soil+amendment mixtures. The ANC is the quantity of acid or base (meq $\mathrm{kg}^{-1}$ ) required to shift the initial $\mathrm{pH}$ of the sample to a $\mathrm{pH}$ of 4 . Thus, the ANC parameter permits an estimation of the buffering capacity of the soils and resulting mixtures over external acidic stresses of samples with an initial $\mathrm{pH}$ higher than 4.

\section{5. $p H_{\text {stat }}$ leaching test}

The $\mathrm{pH}_{\text {stat }}$ leaching test, based on the CEN/TS 14997 protocol (CEN/TS, 2006b), allowed the examination of metal release as a function of $\mathrm{pH}$. Six grams of soil sample or soil+amendment mixtures were suspended in a given volume of deionised water to obtain a liquid-solid ratio of $10 \mathrm{~mL} \mathrm{~g}^{-1}$. Based on the information provided by the $\mathrm{pH}$ titration test, an appropriate amount of acid $\left(\mathrm{HNO}_{3}\right)$ or base $(\mathrm{NaOH})$ was added to modify the initial $\mathrm{pH}$ of the sample to achieve $\mathrm{pH}$ values between 2 and 12. A minimum of eight suspensions covering the $\mathrm{pH}$ range were prepared for each sample. Sample suspensions were stirred for 7 days, which 
is the recommended contact time for the characterisation of samples with a particle size lower than $2 \mathrm{~mm}$ (Kosson et al., 2002). The pH was maintained by adding small quantities of acid (0.1-1 mol L $\left.\mathrm{L}^{-1} \mathrm{HNO}_{3}\right)$ or base $\left(0.3-1 \mathrm{~mol} \mathrm{~L}^{-1} \mathrm{NaOH}\right)$, in order to minimise changes in the solid:liquid ratio, using an automatic pH control device (Model pH-103 Adasa Sistemas). Finally, the suspensions were centrifuged and filtered through $0.45 \mu \mathrm{m}$ pore size nylon membranes and stored until analysis. Experiments were performed in triplicates. The concentrations of trace elements in the extracts were determined by ICP-OES, or by ICP-MS when lower detection limits were required.

\subsection{Data treatment}

Results provided were presented as mean values of 2-3 replicates, depending of the parameters characterized and the test applied. When relevant, one standard deviation was also given. Statistical analyses to compare the average results of the different treatments (Figure 3) were performed using a multiple rank test based on Fisher's least significance differences (at $\mathrm{p}=0.05$ significance). Analyses were carried out using Statgraphics software (version 16.1.11).

\section{Results and discussion}

\subsection{Main characteristics of untreated soils}

Table 1 summarises the main soil characteristics of the untreated soil samples, as well as the total and water-soluble concentrations of the target metals in the soils. Soils had low organic matter content, with LOI values within the $0.5-3.2 \%$ range, and a loamy texture. Field capacity values were similar in all soils tested, within the $24-35 \%$ range. The ASCO soil had neutral $\mathrm{pH}$, low $\mathrm{CEC}$ and high carbonate content. The $\mathrm{S} 15$ soil had a slightly acidic $\mathrm{pH}$, low CEC, and medium carbonate content. The RIB and QUE soils had a slightly acidic pH, low 
CEC (6.9 and $13.3 \mathrm{cmol}_{\mathrm{c}} \mathrm{kg}^{-1}$, respectively), and a non-quantifiable carbonate content. Finally, the TENF soil had the most acidic $\mathrm{pH}$ and the highest CEC among the soils tested.

Total metal concentrations were highest in the S15 soil, followed by the ASCO and TENF soils, whereas the QUE and RIB soils had the lowest values. Comparison of these data with the reference limits for heavy metal content for agricultural and industrial soils for two autonomous regions of Spain (see Table S1 in the Supplementary Material) showed that all soils exceeded the reference levels for agricultural use for $\mathrm{Cd}, \mathrm{Cu}, \mathrm{Pb}$ and $\mathrm{Zn}$. ASCO, TENF and S15 also exceeded the maximum limits established for industrial soils for at least two metals. The water-soluble metal content was small with respect to the total content $(<2 \%)$ in ASCO, QUE, S15 and RIB, with the exception of $\mathrm{Ni}$ and $\mathrm{Zn}$ in RIB (8\% and 4\%, respectively), and $\mathrm{Cd}$ in S15 (58\%). On the contrary, water-soluble metal was proportionally higher in TENF, with yields generally over $15 \%$ for all metals. Due to the high total metal concentration, low extraction yields were not necessarily related to low extractable concentrations (expressed in $\mathrm{mg} \mathrm{kg}^{-1}$ ). Therefore, the extractable concentrations were compared with the recommended limits for acceptance of waste at landfill sites according to the European Council Decision 2003/33/CE (European Council, 2003) for the management of waste (see Table S2). The water-soluble metal in ASCO, QUE and RIB exceeded the limits for inert waste for a few metals, and the soils could thus be classified as non-hazardous wastes, whereas S15 and TENF exceeded the thresholds for hazardous wastes for Cd and Zn in both soils and for $\mathrm{Ni}$ and $\mathrm{Cu}$ in TENF.

\subsection{Effect of amendment on $\mathrm{pH}$ and buffering capacity of soil}

Fig. 1 shows the $\mathrm{pH}$ titration curves for the untreated soils and soil+amendment mixtures, which represent the changes in sample $\mathrm{pH}$ when adding base (negative values) or acid (positive values). Table 2 presents the initial $\mathrm{pH}$ in the experimental conditions of the titration test, and related ANC values of soils and mixtures. ANC and $\mathrm{pH}$ values for the amendments 
are also included for comparison purposes (Venegas et al., 2015). Note that the added $\mathrm{acid} / \mathrm{base}$ is represented in meq $\mathrm{g}^{-1}$ in the titration curves, while the resulting ANC values are expressed in meq $\mathrm{kg}^{-1}$.

TENF and RIB showed the smallest ANC values. The low ANC for the TENF soil was consistent with its initially acidic $\mathrm{pH}$ (4.6). The titration curves of these soils revealed a marked decrease in $\mathrm{pH}$ upon addition of a small aliquot of acid, which was attributed to their low buffering capacity, and consistent with the absence of carbonate phases in these soils. In contrast, the S15 and ASCO soils showed distinctive titration curves with an inflection point at around $\mathrm{pH} 8$, attributed to the neutralisation of carbonates, which were relatively abundant in these two samples (see Table 1). Consequently, these soils showed the highest ANC values among the tested soils. In fact, the ANC of the ASCO soil was as high as the highest ANC of the examined amendments $\left(\mathrm{GW}, 7100 \mathrm{meq} \mathrm{kg}^{-1}\right)$. Therefore, a greater effect on $\mathrm{pH}$ and ANC could be expected following the addition of amendments to TENF, RIB and QUE than to ASCO and S15 soils.

This was confirmed when analysing the resulting mixtures, as summarized in Table 2. The largest changes were noticed for the TENF soil, with an increase in $\mathrm{pH}$ of around 2 units and related increases in ANC of one order of magnitude when the amendments with the highest ANC were added (mixtures containing MOW and GW). Therefore, a positive effect of the addition of the amendments can be anticipated in terms of shifting the $\mathrm{pH}$ of the soils with initial low ANC values (as here TENF, RIB, and QUE soils) to higher $\mathrm{pH}$ values in which the extractable fraction of metals could be decreased, as observed in previous works in which organic amendments were also used (Houben et al., 2013). This hypothesis will be examined in a following section. 


\subsection{Effect of amendment on DOC in the soil+amendment mixtures}

As suggested in a previous study (Clemente et al., 2007), organic matter, either in the solid phase or dissolved in the soil solution, might play a key role in the mobility of heavy metals in soils. Therefore, we tested the effect of the addition of the organic amendments on the changes in DOC content in soil+amendment mixtures. Table 2 shows the DOC values of amendments, soils and soil+amendment mixtures at the initial $\mathrm{pH}$ of the samples. The DOC content of the soils was low (within the $10-50 \mathrm{mg} \mathrm{C} \mathrm{L}^{-1}$ range), which was consistent with their low organic matter content (Rigol et al., 2009; González-Núñez et al., 2012). The DOC content in the amendments was around one order of magnitude higher than in soils, with the exception of the BF biochar. At the doses assayed, it was expected that the MOW amendment would provoke the largest increases in DOC values of the soil+amendment mixtures, as confirmed by the results presented in Table 2, especially for the soils with the lowest DOC values (S15 and ASCO). The DOC values in the mixtures were within the $10-60 \mathrm{mg} \mathrm{C} \mathrm{\textrm {L } ^ { - 1 }}$ range, with values slightly higher for the mixtures with MOW (45-95 $\mathrm{mg} \mathrm{C} \mathrm{L}^{-1}$ ), generally lower than two-fold the initial DOC content in untreated soils. Thus, the effect of the increase in DOC in the mixtures on metal extractability at the initial $\mathrm{pH}$ could be expected to be minor and balanced out by the increase in the sorption capacity of the resulting mixture.

Besides analysing the DOC status at initial $\mathrm{pH}$, DOC was also quantified in selected extracts obtained from the application of the $\mathrm{pH}_{\text {stat }}$ leaching test, thus permitting to examine changes in DOC at different $\mathrm{pH}$ values. DOC data within the $1.5-13 \mathrm{pH}$ range for soils and amendments are shown in Fig. S1 of the Supplementary Material, whereas DOC data at the lowest and highest $\mathrm{pH}$ analysed for soils and mixtures are summarised in Table 3 . The five studied soils followed a similar pattern with minimum DOC values around $\mathrm{pH}$ 6-8. Under more acidic conditions, all soils showed an increase in the DOC content in the extracts. At high $\mathrm{pH}(>10)$, all soils apart from S15 also exhibited an increase in DOC values in the extracts, with maximum values at around $\mathrm{pH}$ 12. This pattern was consistent with the $\mathrm{pH}-$ 
dependent solubilisation of humic and fulvic acids (Van der Sloot, 2002). Regarding amendments, the DOC curves also followed a U-shaped pattern, especially in the case of the MOW and GW amendments, except for the BF biochar that showed only a slight DOC increase at high $\mathrm{pH}$. The maximum DOC content was $1200 \mathrm{mg} \mathrm{C} \mathrm{L}^{-1}$ at $\mathrm{pH} 2$ for MOW, which was 2-fold higher than at initial $\mathrm{pH}$, and $1400 \mathrm{mg} \mathrm{C} \mathrm{L}^{-1}$ at $\mathrm{pH} 12$ for GW (around a 9fold increase with respect to the DOC content at initial $\mathrm{pH}$ ). BS, and especially BF, showed DOC values similar to those obtained in soils (always lower than $300 \mathrm{mg} \mathrm{C} \mathrm{L}^{-1}$ for BF). As observed in Table 3, DOC concentrations for soil+amendment mixtures at strong alkaline and acidic $\mathrm{pH}$ values were systematically higher than at the initial $\mathrm{pH}$ (4- and 7-fold higher at acid and basic $\mathrm{pH}$ on average, respectively), with DOC contents up to 20 times higher than at the initial $\mathrm{pH}$, due to the simultaneous increase in DOC in soils and amendments. However, the direct comparison between the DOC content of soils and soil+amendment mixtures showed that addition of amendments resulted in more than a 2-fold rise in DOC concentrations in the mixtures with respect to the soils only for the S15 and for most soils when using the MOW material, under acidic conditions. At basic $\mathrm{pH}$, the increase was only relevant for the $\mathrm{S} 15$ soil. As changes in DOC concentrations in the mixtures with respect to the untreated soils were only significant in a few cases (mainly for the S15 soil, which had the lowest DOC among the soils tested), it thus could be anticipated that DOC is not having a major effect on the extractable concentrations of heavy metals following the addition of amendments.

\subsection{Extractability pattern of heavy metals}

Fig. 2 shows the pH-dependent extractability curves of heavy metals $(\mathrm{Cd}, \mathrm{Cu}, \mathrm{Ni}, \mathrm{Pb}$ and $\mathrm{Zn})$ for untreated soils and soil+amendment mixtures. The extractability curves of the untreated soils were rescaled with a factor of 0.9 to correct for the dilution effect due to amendment addition at $10 \%$ dose, thus allowing a direct discussion of the effect of the addition of the 
amendment without taking into consideration the dilution effect on extractable metal concentration.

A strong dependence of the extractable metal concentrations with respect to $\mathrm{pH}$ was noticed in all cases. Curve patterns were similar for all metals in the RIB, QUE and TENF soils, in which larger extraction yields were generally observed at strongly acidic $\mathrm{pH}$ values, with much lower extractability at neutral and alkaline $\mathrm{pH}$ (generally lower than $2 \%$ ). This pattern was consistent with the competitive effect of protons at acidic $\mathrm{pH}$ for the sorption sites, as well as with the positively charged surfaces at acidic $\mathrm{pH}$, the slight increase in DOC and the partial dissolution of the mineral phases in soils (Dijkstra et al., 2004; Sastre et al., 2004). In the case of RIB soil, the curves also showed a significant increase in metal extractability at strongly alkaline $\mathrm{pH}$, except for $\mathrm{Ni}$. This increase was also observed for $\mathrm{Pb}$ and $\mathrm{Zn}$ in a few soils, probably due to the formation of soluble hydroxyl carbonate complexes, especially for those soils with a significant carbonate content (ASCO and S15), or of hydroxyl complexes (Dijkstra et al., 2006).

The addition of amendments did not generally alter the curve patterns in the mixtures with respect to those of the untreated soils, as already reported for similar amendments (Houben et al., 2013). However, minor changes were noticed in a few cases, probably explained by an increase in the sorption sites following the addition of the amendments (e.g., see ASCO and S15 mixtures with MOW and GW for $\mathrm{Cd}$ and $\mathrm{Zn}$ in the acidic $\mathrm{pH}$ range, and for $\mathrm{Pb}$ at high pH). As previously reported (Venegas et al., 2015), MOW showed high sorption capacity for $\mathrm{Cd}, \mathrm{GW}$ for $\mathrm{Pb}$ and $\mathrm{Zn}$, and $\mathrm{BS}$ for $\mathrm{Cu}, \mathrm{Zn}$ and $\mathrm{Pb}$, which partially explains minor changes observed in a few cases in the leaching pattern of the metals in the mixtures with respect to untreated soils. 


\subsection{Extractability of heavy metals at initial $\mathrm{pH}$}

Besides examining the role of the amendments across the entire $\mathrm{pH}$ range, we also assessed the effect of the addition of the amendments at the initial $\mathrm{pH}$ of the mixtures. Fig. 3 displays the extractable metal concentrations at initial $\mathrm{pH}$ for soil and soil+amendment mixtures. European Council Decision threshold limits for "inert waste" (black line), "non-hazardous waste" (cyan dotted line) and "hazardous waste" (red dashed line) are also indicated.

Regardless of the total and extractable metal concentrations, which were higher or lower depending on the particular soil and metal, extraction yields $(\%)$ were generally low $(<2 \%)$ at the initial $\mathrm{pH}$, with the exception of $\mathrm{Cd}, \mathrm{Cu}, \mathrm{Ni}$ and $\mathrm{Zn}$ in TENF, Ni and $\mathrm{Zn}$ in $\mathrm{RIB}$ and $\mathrm{Cd}$ in $\mathrm{S} 15$. However, for those cases in which total metal concentration was high, even low extraction yields could lead to extractable metal concentrations that exceed the recommended limits for the acceptance of inert or non-hazardous wastes (even the hazardous waste threshold for the TENF soil).

In general, amendments reduced the extractable metal concentration at the initial $\mathrm{pH}$ of the resulting mixtures. The efficacy of the amendments varied according to the initial soil ANC and $\mathrm{pH}$, metal extraction yield and sorption capacity of the materials (quantified through the solid-liquid distribution coefficient, $\mathrm{K}_{\mathrm{d}}$ (Venegas et al., 2015)). In this sense, our observations consistently differed from those of previous studies that reported an increase in heavy metal extractability in soils upon addition of organic amendments, partially attributable to an increase in the DOC content, which formed soluble chelates with heavy metals in solution, competing with the binding sites in the solid phase (Schwab et al., 2007; van Herwijnen et al., 2007). As the amendments examined here had a minor effect on the DOC, this detrimental effect of metal extractability could be disregarded.

Although the ASCO soil already had a high buffer capacity and $\mathrm{pH}$, the addition of GW, BF and BS led to a large reduction in the extractable $\mathrm{Cu}$ concentrations, which could be explained by a 
significant increase in specific sorption sites in the resulting mixtures, consistent with the relatively high $\mathrm{K}_{\mathrm{d}}$ values quantified for these amendments for $\mathrm{Cu}$ (Venegas et al., 2015). Significant reductions were also observed for extractable $\mathrm{Cd}, \mathrm{Pb}$ and $\mathrm{Zn}$ concentrations in this soil (from 0.4 to $0.13 \mathrm{mg} \mathrm{kg}^{-1}$ for $\mathrm{Cd}, 9$ to $2 \mathrm{mg} \mathrm{kg}^{-1}$ for $\mathrm{Pb}$ and 7.3 to $1.6 \mathrm{mg} \mathrm{kg}^{-1}$ for $\mathrm{Zn}$ ) following addition of the MOW amendment, also consistent with the $\mathrm{K}_{\mathrm{d}}$ values of this amendment (over 103 $\mathrm{L} \mathrm{kg}^{-1}$ in all cases (Venegas et al., 2015)). These results are consistent with reductions in extractable $\mathrm{Cd}$ and $\mathrm{Zn}$ concentrations observed when adding compost to contaminated soils (Beesley et al., 2010). The positive effect of the addition of MOW in terms of reducing the extractable metal concentration was also observed in S15 soil for Cd $\left(5950 \mathrm{mg} \mathrm{kg}^{-1}\right.$ to $1900 \mathrm{mg}$ $\left.\mathrm{kg}^{-1}\right)$ and $\mathrm{Zn}\left(6650 \mathrm{mg} \mathrm{kg}^{-1}\right.$ to $\left.1910 \mathrm{mg} \mathrm{kg}^{-1}\right)$, although this soil also had high initial ANC and $\mathrm{pH}$ values. However, the addition of the amendments did not change the ASCO and S15 waste categories. RIB soil showed a significant reduction in Ni (from $1.9 \mathrm{mg} \mathrm{kg}^{-1}$ to $0.02 \mathrm{mg} \mathrm{kg}^{-1}$ ), Zn (13.5 $\mathrm{mg} \mathrm{kg}^{-1}$ to $\left.1 \mathrm{mg} \mathrm{kg}^{-1}\right)$ and $\mathrm{Cd}\left(0.1 \mathrm{mg} \mathrm{kg}^{-1}\right.$ to $\left.0.007 \mathrm{mg} \mathrm{kg}^{-1}\right)$ extractability, likely because of the combination of an increase in $\mathrm{pH}$ and an increase in specific sorption due to the addition of amendment, although the $\mathrm{pH}$ effect is expected to be dominant (Sauvé et al., 1997). For this soil, the addition of the amendments would generally lead to extractable concentrations lower than the thresholds for inert waste. A similar pattern was also observed for $\mathrm{Ni}$ and $\mathrm{Zn}$ in the case of the QUE soil.

TENF soil was originally over the threshold concentrations for hazardous wastes for all metals. Addition of the amendments significantly reduced the metal concentrations, often by almost two orders of magnitude depending on the amendment. These large reductions in metal extractability could be related to the large effect on $\mathrm{pH}$ caused by the addition of the amendments, and additionally to the high $\mathrm{K}_{\mathrm{d}}$ of the MOW and GW amendments (Venegas et al., 2015). The observed pattern is consistent with previous studies that observed similar reductions in metal extractable concentrations following the addition of organic amendments to an acidic soil (Pardo 
et al., 2014). These significant reductions in metal extractable concentrations modified the waste classification of the TENF soil, which subsequently fell below the hazardous waste threshold, and also under the non-hazardous waste threshold for all metals when using MOW and GW amendments.

\section{Conclusions}

Laboratory experiments identified the organic amendments that were most effective in reducing the extractable concentrations of heavy metals in contaminated soils. Besides an increase in the metal sorption capacity in the resulting mixtures, a beneficial effect that might be minor given the low doses at which the amendments are added to contaminated soils (and given that $\mathrm{K}_{\mathrm{d}}$ values over $10^{4} \mathrm{~L} \mathrm{~kg}^{-1}$ would be required to observe consistent effects), key aspects are how the DOC, ANC and $\mathrm{pH}$ status may vary in the resulting soil+amendment mixtures. Amendments can increase the $\mathrm{pH}$ and ANC values of acid soils and/or soils with low initial buffering capacity, whereas the effect in soils with high buffering capacity is smaller. The effect of $\mathrm{pH}$ and ANC modifications upon amendment was clearly observed here for the RIB and especially TENF soils, which had an acidic initial $\mathrm{pH}$ that was raised by $2-3$ $\mathrm{pH}$ units following amendment addition in all cases, and resulted in a general lowering of extractable heavy metal concentrations. Thus, the use of organic amendments in the remediation of soils is especially recommended for acid soils, but only after confirming that their addition would not increase the DOC in the resulting mixtures. However, as the increase in $\mathrm{pH}$ and $\mathrm{ANC}$ were the main driving mechanisms leading to the decrease in metal extractability, attention should be paid when applying these materials at field level to ensure that the increases in $\mathrm{pH}$, which may be reversible, are maintained over time. 


\section{Acknowledgements}

This research was supported by the Ministerio de Economía y Competitividad (Projects CTM2011-27211 and CTM2014-55191-R) and Generalitat de Catalunya (AGAUR contract 2014SGR1277). ICP-OES and ICP-MS analyses were carried out at the CCiT of the Universitat de Barcelona. The authors would like to thank Ecoparc de Barcelona for the supply of MOW material. A.V. thanks CONICYT Chile for a predoctoral fellowship.

\section{References}

Adriano, D.C., 2001. Trace elements in terrestrial environments: Biogeochemistry, bioavailability and risks of metals, 2nd ed. Springer, New York, NY, USA.

Beesley, L., Moreno-Jiménez, E., Gomez-Eyles, J.L., 2010. Effects of biochar and greenwaste compost amendments on mobility, bioavailability and toxicity of inorganic and organic contaminants in a multi-element polluted soil. Environ. Pollut. 158, 2282-2287.

Bower, C.A., Reitemeier, R.F., Fireman, M., 1952. Exchangeable cation analysis of saline and alkaline soils. Soil Sci. 73, 251-261.

Burt, R., 2004. Soil survey laboratory methods manual, Investigations Reports No 42, Version 4.0. Natural Resources Conservation Services.USDA, U.S. Department of Agriculture. Washington.

Cappuyns, V., Swennen, R., 2008. The application of pH(stat) leaching tests to assess the pHdependent release of trace metals from soils, sediments and waste materials. J. Hazard. Mater. 158, 185-195.

CEN/TS, 2006a. CEN/TS 15364. Characterization of waste. Leaching behaviour test. Acid and basic neutralization capacity test. European Comitee of Standarization, Brussels. 
CEN/TS, 2006b. CEN/TS 14997. Characterization of waste. Leaching behaviour test. Influence of $\mathrm{pH}$ on leaching with continuous $\mathrm{pH}$-control. European Comitee of Standarization, Brussels.

Clemente, R., Paredes, C., Bernal, M.P., 2007. A field experiment investigating the effects of olive husk and cow manure on heavy metal availability in a contaminated calcareous soil from Murcia (Spain). Agr. Ecosyst. Env. 118, 319-326.

Dijkstra, J.J., Meeussen, J.C.L., Comans, R.N.J., 2004. Leaching of heavy metals from contaminated soils: an experimental and modeling study. Environ. Sci. Technol. 38, $4390-4395$.

Dijkstra, J.J., Van der Sloot, H.A., Comans, R.N.J., 2006. The leaching of major and trace elements from MSWI bottom ash as a function of $\mathrm{pH}$ and time. Appl. Geochemistry 21, $335-351$.

DIN, 1984. DIN 38414-S4, 1984. German standard methods for the examination of water, waste water and sludge. Group S (sludge and sediments). Determination of leachability by water (S4). Normung, Berlin.

European Council, 2003. European Council Decision 2003/33/CE establishing criteria and procedure for the acceptance of waste at landfills pursuant to Article 16 and Annex II to Directive 1999/31/EC. Off. J. Eur. Communities , EU Commision, Brussels.

González-Núñez, R., Alba, M.D., Orta, M.M., Vidal, M., Rigol, A., 2012. Remediation of metal-contaminated soils with the addition of materials - part II: leaching tests to evaluate the efficiency of materials in the remediation of contaminated soils. Chemosphere 87, 829-837. 
Houben, D., Evrard, L., Sonnet, P., 2013. Mobility, bioavailability and pH-dependent leaching of cadmium, zinc and lead in a contaminated soil amended with biochar. Chemosphere 92, 1450-1457.

Kosson, D.S., Van der Sloot, H. a., Sanchez, F., Garrabrants, A.C., 2002. An Integrated Framework for Evaluating Leaching in Waste Management and Utilization of Secondary Materials. Environ. Eng. Sci. 19, 159-204.

Kumpiene, J., Lagerkvist, A., Maurice, C., 2008. Stabilization of $\mathrm{As}, \mathrm{Cr}, \mathrm{Cu}, \mathrm{Pb}$ and $\mathrm{Zn}$ in soil using amendments--a review. Waste Manag. 28, 215-225.

Lombi, E., Zhao, F., Zhang, G., Sun, B., Fitz, W., Zhang, H., Mcgrath, S.P., 2002. In situ fixation of metals in soils using bauxite residue : chemical assessment. Environ. Pollut. $118,435-443$.

Mueller, G., Gastner, M., 1971. The "Karbonat-Bombe", a simple device for the determination of the carbonate content in sediments, soils, and other materials. Neues Jahrb. Miner. Monatsh 10, 466-469.

Nwachukwu, O.I., Pulford, I.D., 2009. Soil metal immobilization and ryegrass uptake of lead, copper and zinc as affected by application of organic materials as soil amendments in a short-term greenhouse trial. Soil Use Manag. 25, 159-167.

Pardo, T., Bernal, M.P., Clemente, R., 2014. Efficiency of soil organic and inorganic amendments on the remediation of a contaminated mine soil: I. Effects on trace elements and nutrients solubility and leaching risk. Chemosphere 107, 121-128.

Park, J.H., Lamb, D., Paneerselvam, P., Choppala, G., Bolan, N., Chung, J.-W., 2011. Role of organic amendments on enhanced bioremediation of heavy metal(loid) contaminated soils. J. Hazard. Mater. 185, 549-574. 
Rigol, A., Mateu, J., González-Núñez, R., Rauret, G., Vidal, M., 2009. pH(stat) vs. single extraction tests to evaluate heavy metals and arsenic leachability in environmental samples. Anal. Chim. Acta 632, 69-79.

Sastre, J., Hernández, E., Rodríguez, R., Alcobé, X., Vidal, M., Rauret, G., 2004. Use of sorption and extraction tests to predict the dynamics of the interaction of trace elements in agricultural soils contaminated by a mine tailing accident. Sci. Total Environ. 329, $261-281$.

Sauvé, S., McBride, M.B., Norvell, W.A., Hendershot, W.H., 1997. Copper Solubility and Speciation of In Situ Contaminated Soils: Effects of Copper Level, pH and Organic Matter. Water. Air. Soil Pollut. 100, 133-149.

Schwab, P., Zhu, D., Banks, M.K., 2007. Heavy metal leaching from mine tailings as affected by organic amendments. Bioresour. Technol. 98, 2935-2941.

USEPA, 2008. Method 3052. Microwave assisted acid digesmiots of siliceous and organically based matrices, in: Test Methods for Evaluating Solid Waste. Physical/Chemical Methods. SW-546. USEPA. Washington D.C.

Van der Sloot, H.A., 1990. Leaching Behaviour of Waste and Stabilized Waste Materials; Characterization for Environmental Assessment Purposes. Waste Manag. Res. 8, 215228.

Van der Sloot, H.A., Comans, R.N.J., Hjelmar, O., 1996. Similarities in the leaching behaviour of trace contaminants from waste, stabilized waste, construction materials and soils. Sci. Total Environ. 178, 111-126.

Van der Sloot, H.A., 2002. Harmonisation of Leaching/Extraction Procedures for Sludge, Compost, Soil and Sediment Analyses, in: Quevauviller, P. (Ed.), Methodologies for Soil 
and Sediments Franctionation Studies. Royal Society of Chemistry, Cambridge, UK, pp. $142-174$

Van Herwijnen, R., Laverye, T., Poole, J., Hodson, M.E., Hutchings, T.R., 2007. The effect of organic materials on the mobility and toxicity of metals in contaminated soils. Appl. Geochemistry 22, 2422-2434.

Venegas, A., Rigol, A., Vidal, M., 2015. Viability of organic wastes and biochars as amendments for the remediation of heavy metal-contaminated soils. Chemosphere 119, $190-198$. 


\section{Table 1}

Soil characteristics

\begin{tabular}{|c|c|c|c|c|c|c|c|c|c|c|c|c|c|c|c|}
\hline Soil & $\mathrm{pH}$ & $\begin{array}{l}\text { Moisture } \\
(\%)\end{array}$ & $\begin{array}{l}\mathrm{FC} \\
(\%)\end{array}$ & $\begin{array}{l}\text { LOI } \\
(\%)\end{array}$ & $\begin{array}{l}\mathrm{CaCO}_{3} \\
(\%)\end{array}$ & $\begin{array}{l}\text { CEC } \\
\left(\mathrm{cmolc} \mathrm{kg}^{-1}\right)\end{array}$ & $\begin{array}{l}\text { Sand } \\
(\%)\end{array}$ & $\begin{array}{l}\text { Clay } \\
(\%)\end{array}$ & Texture & & $\begin{array}{l}\mathrm{Cd} \\
(\mathrm{mg} / \mathrm{kg})\end{array}$ & $\begin{array}{l}\mathrm{Cu} \\
(\mathrm{mg} / \mathrm{kg})\end{array}$ & $\begin{array}{l}\mathrm{Ni} \\
(\mathrm{mg} / \mathrm{kg})\end{array}$ & $\begin{array}{l}\mathrm{Pb} \\
(\mathrm{mg} / \mathrm{kg})\end{array}$ & $\begin{array}{l}\mathrm{Zn} \\
(\mathrm{mg} / \mathrm{kg})\end{array}$ \\
\hline ASCO & 7.0 & 2.1 & 24 & 0.5 & 36 & 4.1 & 28.5 & 8.2 & Silty loam & $\begin{array}{l}\text { TC } \\
\text { WS }\end{array}$ & $\begin{array}{l}30 \\
0.4\end{array}$ & $\begin{array}{l}11040 \\
37\end{array}$ & $\begin{array}{l}230 \\
1.0\end{array}$ & $\begin{array}{l}5375 \\
8.9\end{array}$ & $\begin{array}{l}1835 \\
7.3\end{array}$ \\
\hline QUE & 6.2 & 3.4 & 32 & 3.2 & $<1 . q$ & 13.3 & 51.2 & 5.6 & Sandy loam & $\begin{array}{l}\text { TC } \\
\text { WS }\end{array}$ & $\begin{array}{l}12 \\
0.1\end{array}$ & $\begin{array}{l}380 \\
0.9\end{array}$ & $\begin{array}{l}20 \\
0.7\end{array}$ & $\begin{array}{l}1580 \\
0.01\end{array}$ & $\begin{array}{l}2150 \\
33.5\end{array}$ \\
\hline RIB & 6.2 & 1.1 & 29 & 1.0 & $<1 . q$ & 6.9 & 76.5 & 7.2 & Sandy loam & $\begin{array}{l}\text { TC } \\
\text { WS }\end{array}$ & $\begin{array}{l}4 \\
0.1\end{array}$ & $\begin{array}{l}120 \\
0.4\end{array}$ & $\begin{array}{l}25 \\
1.9\end{array}$ & $\begin{array}{l}265 \\
0.1\end{array}$ & $\begin{array}{l}350 \\
13.5\end{array}$ \\
\hline S15 & 6.4 & 7.9 & 34 & 0.9 & 16 & 13.1 & 63.9 & 9.5 & Sandy loam & $\begin{array}{l}\text { TC } \\
\text { WS }\end{array}$ & $\begin{array}{l}10200 \\
5950\end{array}$ & $\begin{array}{l}16430 \\
6.0\end{array}$ & $\begin{array}{l}150 \\
5.6\end{array}$ & $\begin{array}{l}91520 \\
36\end{array}$ & $\begin{array}{l}275500 \\
6650\end{array}$ \\
\hline TENF & 4.6 & 4.3 & 35 & 1.8 & $<1 . q$ & 48.3 & 38.3 & 25.1 & Loam & $\begin{array}{l}\mathrm{TC} \\
\mathrm{WS}\end{array}$ & $\begin{array}{l}30 \\
7.8\end{array}$ & $\begin{array}{l}2105 \\
316\end{array}$ & $\begin{array}{l}225 \\
95\end{array}$ & $\begin{array}{l}5360 \\
16\end{array}$ & $\begin{array}{l}1810 \\
697\end{array}$ \\
\hline
\end{tabular}

TC: metal total content; WS: water-soluble metal content. 
Table 2

$\mathrm{pH}, \mathrm{ANC}$ and DOC (at initial $\mathrm{pH}$ ) of the amendments, soils and mixtures

\begin{tabular}{|c|c|c|c|}
\hline & $\mathrm{pH}$ & ANC $\left(\right.$ meq $\left.\mathrm{kg}^{-1}\right)$ & $\mathrm{DOC}\left(\mathrm{mg} \mathrm{C} \mathrm{L}^{-1}\right)$ \\
\hline MOW & 8.3 & $4280(150)$ & 530 \\
\hline GW & 8.4 & $7100(190)$ & 160 \\
\hline $\mathrm{BF}$ & 8.9 & $420(10)$ & 10 \\
\hline BS & 10.0 & $725(9)$ & 220 \\
\hline$\overline{\mathrm{ASCO}}$ & 7.7 & $6950(300)$ & 15 \\
\hline $\mathrm{ASCO}+\mathrm{MOW}$ & 7.8 & $6665(150)$ & 50 \\
\hline $\mathrm{ASCO}+\mathrm{GW}$ & 7.7 & $6840(170)$ & 35 \\
\hline $\mathrm{ASCO}+\mathrm{BF}$ & 7.8 & $6190(200)$ & 10 \\
\hline $\mathrm{ASCO}+\mathrm{BS}$ & 7.8 & $6790(120)$ & 35 \\
\hline QUE & 6.9 & $300(50)$ & 30 \\
\hline QUE+MOW & 7.3 & $755(30)$ & 65 \\
\hline QUE+GW & 7.5 & $720(15)$ & 40 \\
\hline QUE+BF & 7.5 & $340(8)$ & 25 \\
\hline QUE+BS & 7.6 & $340(3)$ & 35 \\
\hline RIB & 6.3 & $60(17)$ & 25 \\
\hline RIB+MOW & 7.7 & $290(6)$ & 55 \\
\hline $\mathrm{RIB}+\mathrm{GW}$ & 7.8 & $305(10)$ & 40 \\
\hline $\mathrm{RIB}+\mathrm{BF}$ & 7.6 & $90(4)$ & 20 \\
\hline $\mathrm{RIB}+\mathrm{BS}$ & 7.7 & $95(5)$ & 25 \\
\hline S15 & 6.8 & $1960(150)$ & 10 \\
\hline S15+MOW & 7.1 & $2260(130)$ & 45 \\
\hline S15+GW & 6.9 & $2140(95)$ & 20 \\
\hline $\mathrm{S} 15+\mathrm{BF}$ & 6.7 & $2070(100)$ & 5 \\
\hline S15+BS & 6.9 & $1740(150)$ & 30 \\
\hline TENF & 4.6 & $40(3)$ & 50 \\
\hline TENF+MOW & 7.0 & $365(7)$ & 95 \\
\hline TENF+GW & 7.6 & $440(8)$ & 60 \\
\hline TENF+BF & 7.4 & $75(2)$ & 50 \\
\hline TENF+BS & 6.3 & $195(10)$ & 55 \\
\hline
\end{tabular}


Table 3

DOC content of the soils and mixtures at acidic and alkaline $\mathrm{pH}$

\begin{tabular}{|c|c|c|c|c|c|}
\hline Soil/mixtures & $\mathrm{pH}$ & DOC & Soil/mixtures & $\mathrm{pH}$ & DOC \\
\hline \multirow[t]{2}{*}{$\mathrm{ASCO}$} & 3.2 & 110 & $\mathrm{~S} 15$ & 1.5 & 45 \\
\hline & 12.4 & 105 & & 12.1 & 10 \\
\hline \multirow[t]{2}{*}{ ASCO+MOW } & 3.0 & 290 & S15+MOW & 2.0 & 150 \\
\hline & 12.0 & 115 & & 11.6 & 85 \\
\hline \multirow[t]{2}{*}{$\mathrm{ASCO}+\mathrm{GW}$} & 4.9 & 225 & $\mathrm{~S} 15+\mathrm{GW}$ & 2.0 & 110 \\
\hline & 12.0 & 240 & & 11.4 & 150 \\
\hline \multirow[t]{2}{*}{$\mathrm{ASCO}+\mathrm{BF}$} & 3.7 & 105 & $\mathrm{~S} 15+\mathrm{BF}$ & 2.0 & 45 \\
\hline & 12.5 & 120 & & 12.0 & 30 \\
\hline \multirow[t]{2}{*}{$\mathrm{ASCO}+\mathrm{BS}$} & 2.7 & 140 & $\mathrm{~S} 15+\mathrm{BS}$ & 2.0 & 120 \\
\hline & 12.0 & 180 & & 11.6 & 95 \\
\hline \multirow[t]{2}{*}{ QUE } & 1.6 & 155 & TENF & 1.8 & 160 \\
\hline & 12.1 & 145 & & 12.0 & 360 \\
\hline \multirow{2}{*}{ QUE+MOW } & 2.0 & 255 & TENF+MOW & 2.3 & 265 \\
\hline & 12.2 & 195 & & 12.0 & 370 \\
\hline \multirow[t]{2}{*}{ QUE+GW } & 1.7 & 180 & TENF+GW & 2.6 & 210 \\
\hline & 12.0 & 140 & & 12.0 & 470 \\
\hline \multirow{2}{*}{ QUE+BF } & 1.6 & 140 & TENF+BF & 4.5 & 90 \\
\hline & 11.5 & 160 & & 12.0 & 440 \\
\hline \multirow[t]{2}{*}{ QUE+BS } & 4.0 & 60 & TENF+BS & 2.7 & 140 \\
\hline & 11.8 & 225 & & 12.0 & 465 \\
\hline \multirow[t]{2}{*}{ RIB } & 1.6 & 50 & & & \\
\hline & 12.8 & 250 & & & \\
\hline \multirow[t]{2}{*}{ RIB+MOW } & 2.0 & 85 & & & \\
\hline & 12.5 & 315 & & & \\
\hline \multirow[t]{2}{*}{$\mathrm{RIB}+\mathrm{GW}$} & 3.2 & 75 & & & \\
\hline & 12.6 & 370 & & & \\
\hline \multirow[t]{2}{*}{$\mathrm{RIB}+\mathrm{BF}$} & 2.0 & 30 & & & \\
\hline & 12.4 & 385 & & & \\
\hline \multirow[t]{2}{*}{$\mathrm{RIB}+\mathrm{BS}$} & 2.1 & 135 & & & \\
\hline & 12.3 & 310 & & & \\
\hline
\end{tabular}



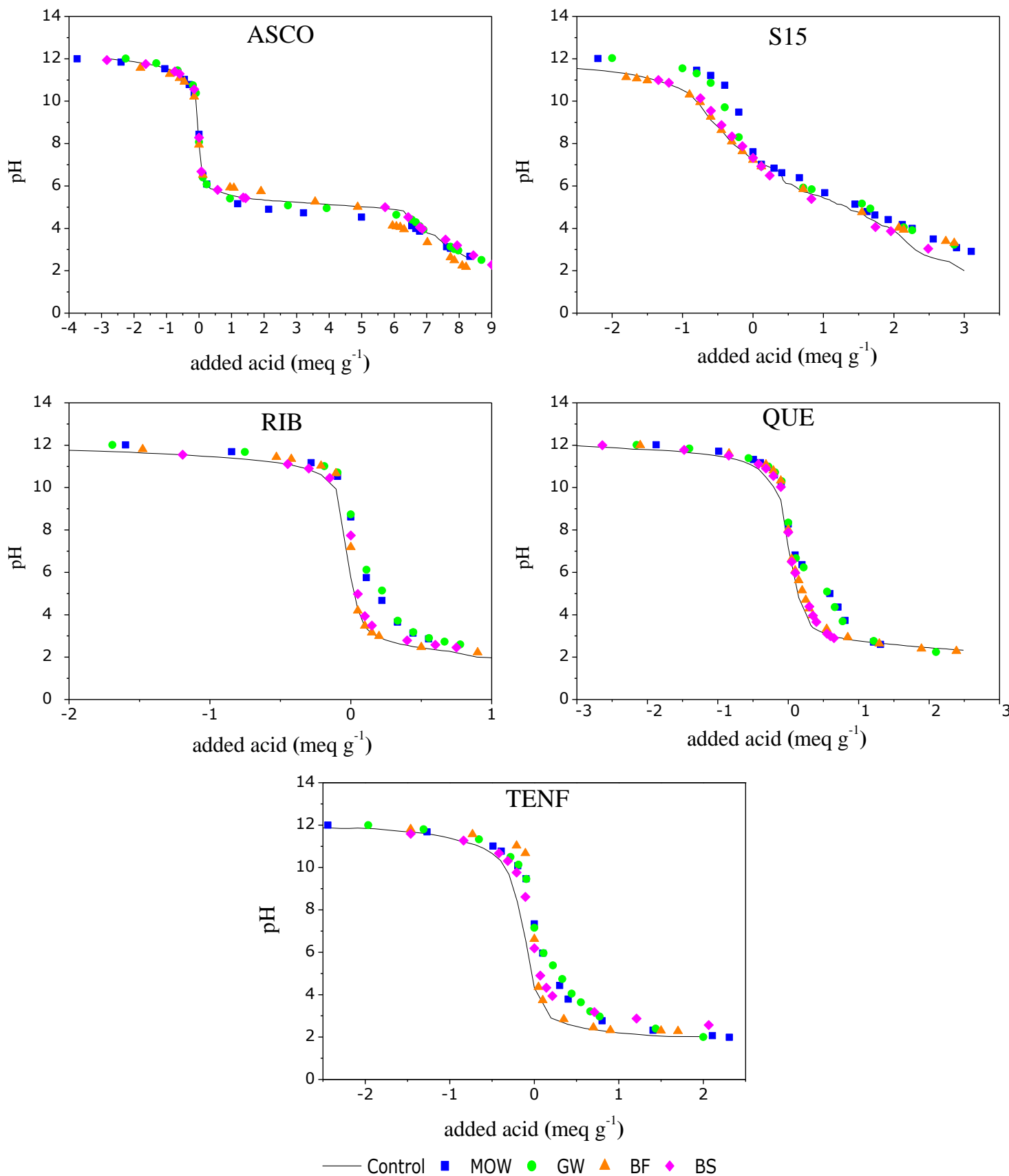

Fig. 1. pH titration curves of soil and soil+amendments mixtures. 


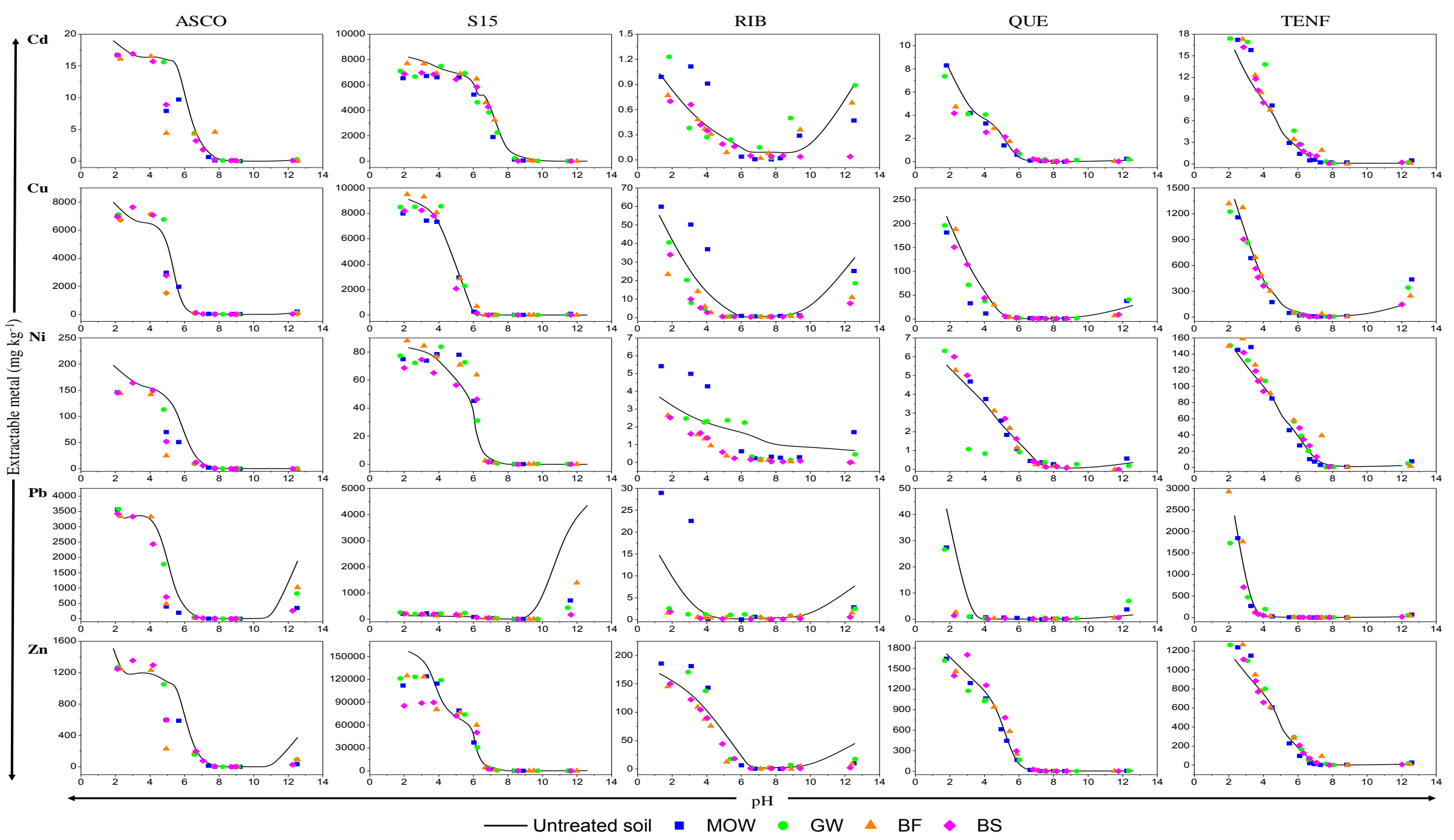

Fig. 2. Metal extractabilityleaching curves (extractable metal $\left(\mathrm{mg} \mathrm{kg}^{-1}\right)$ vs. $\mathrm{pH}$ ) of soil and soil+amendment mixtures. 

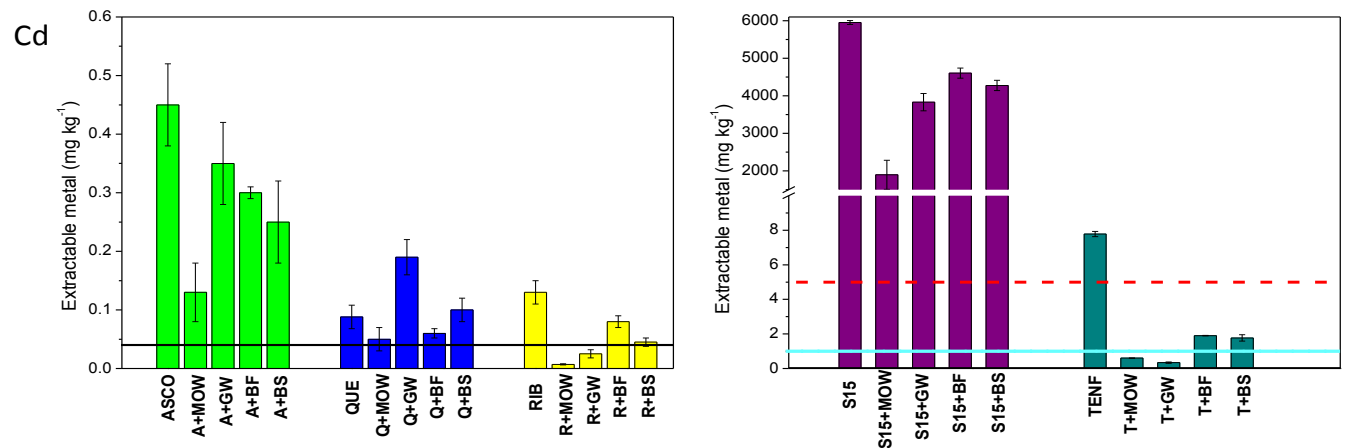

$\mathrm{Cu}$
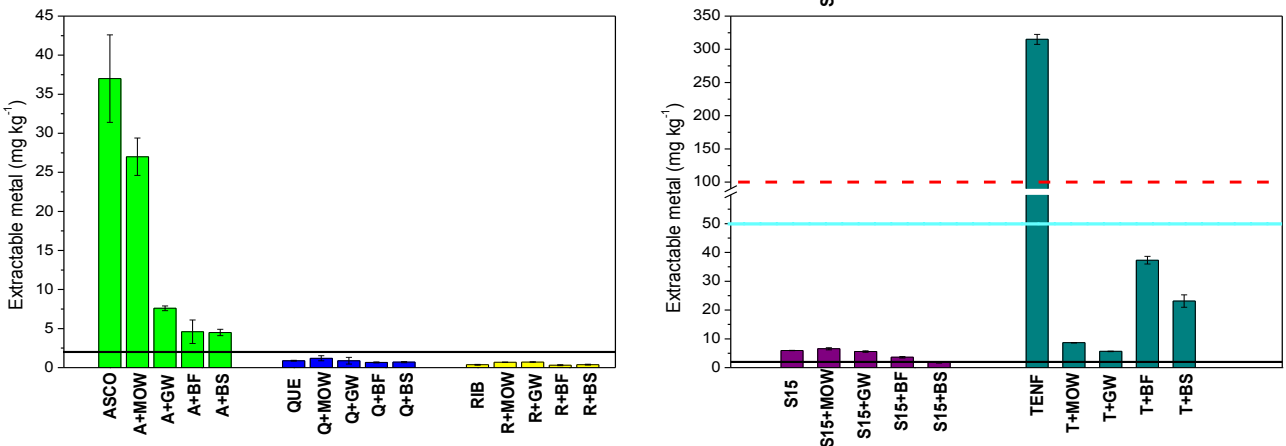

$\mathrm{Ni}$
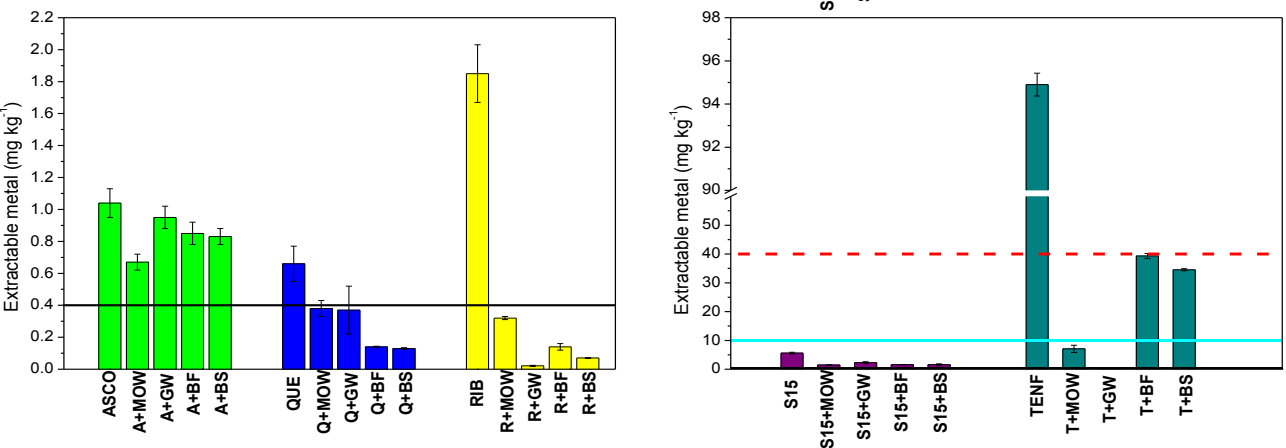

$\mathrm{Pb}$
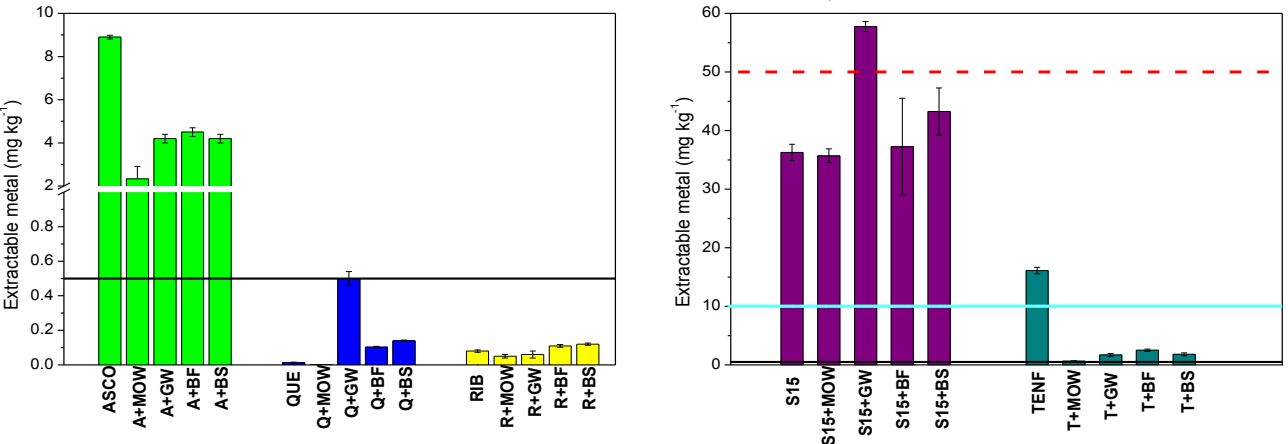

$\mathrm{Zn}$
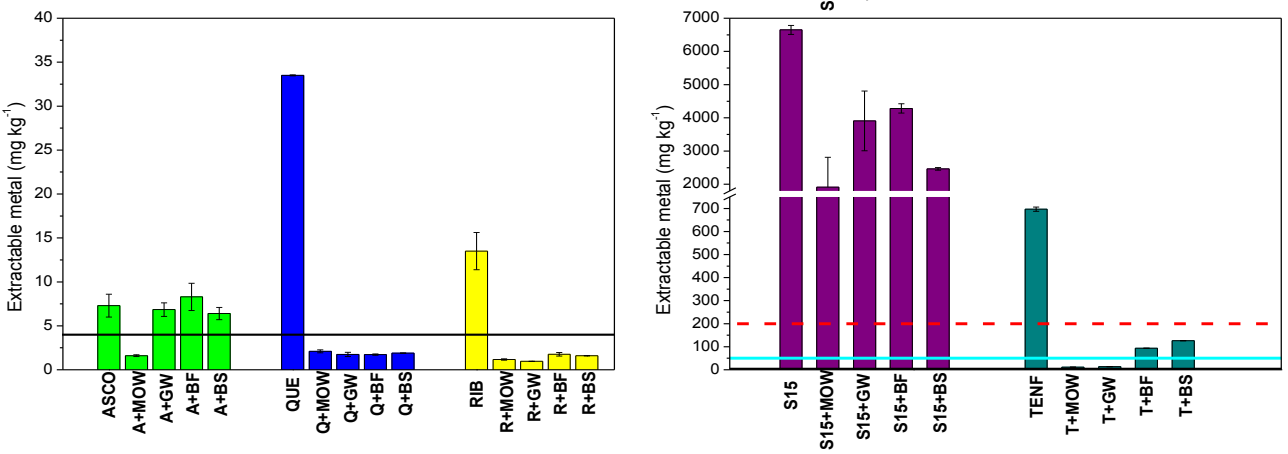

Inert waste $\longrightarrow$ Non-Hazardous waste - - · Hazardous waste

Fig. 3. Extractable metals in soils and soil+amendment mixtures at initial pH. Error bars indicate the standard deviation. 


\section{Supplementary material}

Changes in heavy metal extractability from contaminated soils remediated with organic waste or biochar

Andrea Venegas, Anna Rigol, Miquel Vidal

Departament de Química Analítica, Universitat de Barcelona, Martí i Franquès 1-11,

08028-Barcelona, Spain 


\section{Soil characterization}

CEC was determined after extraction with ammonium acetate (Bower et al., 1952). In short, $5 \mathrm{~g}$ of the material was added to $30 \mathrm{~mL}$ of $95 \%$ ethanol, and the resulting suspension was stirred for $5 \mathrm{~min}$ and centrifuged. Then, the supernatant was discarded. This procedure was repeated three times to remove the soluble salts. Next, $30 \mathrm{~mL}$ of 1 mol L-1 ammonium acetate was added to the remaining solid, and the suspension was stirred for $5 \mathrm{~min}$ and centrifuged. Then, the supernatant was collected in a volumetric flask. The extraction with ammonium acetate was repeated three times, and the supernatants were collected in the same flask. The flask was filled to the reference volume with 1 mol L-1 ammonium acetate. The exchangeable cations were determined in the supernatant by ICP-OES, and the CEC was calculated as the sum of the exchangeable cations.

The total content of trace elements in soil samples was determined by soil digestion in a closed microwave digestion system (Milestone Ethos Touch Control) following an adaptation of the EPA3052 method (USEPA, 2008). In brief, $0.3 \mathrm{~g}$ of sample was weighed in a PTFE vessel and $6 \mathrm{~mL} 69 \% \mathrm{HNO}_{3}, 3 \mathrm{~mL} 40 \% \mathrm{HF}$ and $2 \mathrm{~mL} 30 \% \mathrm{H}_{2} \mathrm{O}_{2}$ were added. The temperature was gradually increased from $25^{\circ} \mathrm{C}$ to $190^{\circ} \mathrm{C}$ over $15 \mathrm{~min}$ followed by a dwell time of $30 \mathrm{~min}$. After a cooling time of $10 \mathrm{~min}, 16 \mathrm{~mL} \mathrm{5 \%} \mathrm{H}_{3} \mathrm{BO}_{3}$ was added to mask the free fluoride ions present in the solution and dissolve fluoride precipitates. The resulting suspension was submitted to the same digestion procedure as in the first stage. After cooling the extracts at room temperature, they were diluted with Milli-Q water to a final volume of $50 \mathrm{~mL}$ and stored in polyethylene bottles at $4^{\circ} \mathrm{C}$ until analysis. The water-soluble metal concentrations were quantified by obtaining water extracts after equilibrating a known amount of the soil or amendment with Milli-Q water in a 1:10 solid:liquid ratio for $48 \mathrm{~h}$ at room temperature (DIN, 1984), Finally, the 
samples were centrifuged, and the water extracts were filtered through a $0.45 \mu \mathrm{m}$ filter and stored at $4{ }^{\circ} \mathrm{C}$ before analysis. Trace elements were determined in the solutions by ICP-OES using a Perkin-Elmer Model OPTIMA 3200RL ICP-OES. The emission lines employed for ICP-OES (Perkin-Elmer Model OPTIMA 3200RL) were (nm) Cd: 214.440 and 228.802; Cu: 324.752 and 327.393; Pb: 220.353; $\mathrm{Zn:} 206.200$ and 213.857; Ca: 315.887 and 317.933; Mg: 279.077 and 285.213; K: 766.490; Na: 330.237 and Ni: 231.604. The detection limits using this technique were $0.01 \mathrm{mg} \mathrm{L}^{-1} \mathrm{Cd} ; 0.01 \mathrm{mg} \mathrm{L}^{-1}$ for $\mathrm{Cu} ; 0.1 \mathrm{mg} \mathrm{L}^{-1}$ for $\mathrm{Ni} ; 0.2 \mathrm{mg} \mathrm{L}^{-1}$ for $\mathrm{Pb}$ and $0.025 \mathrm{mg} \mathrm{L}^{-1}$ for $\mathrm{Zn}$. For samples with lower metal concentrations, a Perkin-Elmer ELAN 6000 inductively coupled plasma mass spectrometer was used (ICP-MS). The detection limits of the ICP-MS measurements were $0.02 \mu \mathrm{g} \mathrm{L}^{-1}$ for $\mathrm{Cd}$; $0.1 \mu \mathrm{g} \mathrm{L} \mathrm{L}^{-1}$ for $\mathrm{Cu} ; 0.2 \mu \mathrm{g} \mathrm{L}^{-1}$ for $\mathrm{Ni} ; 0.05 \mu \mathrm{g} \mathrm{L}^{-1}$ for $\mathrm{Pb}$ and $0.2 \mu \mathrm{g} \mathrm{L} \mathrm{L}^{-1}$ for $\mathrm{Zn}$. 


\section{Table S1}

Reference limits $\left(\mathrm{mg} \mathrm{kg}^{-1}\right)$ of metal total concentration in soils (data gathered from regulations of Catalunya and Andalucía autonomous regions in Spain)

\begin{tabular}{lll}
\hline Metal & Agricultural use & Industrial use \\
\hline $\mathrm{Cd}$ & $2-3$ & 55 \\
$\mathrm{Cu}$ & $50-100$ & 1000 \\
$\mathrm{Ni}$ & $40-50$ & 1000 \\
$\mathrm{~Pb}$ & $60-200$ & 550 \\
$\mathrm{Zn}$ & $170-300$ & 1000 \\
\hline
\end{tabular}




\section{Table S2}

Threshold limits $\left(\mathrm{mg} \mathrm{kg}^{-1}\right)$ of water soluble metal concentrations (European Council, 2003)

\begin{tabular}{llll}
\hline Metal & Inert waste & Non-hazardous waste & Hazardous waste \\
\hline $\mathrm{Cd}$ & 0.04 & 1 & 5 \\
$\mathrm{Cu}$ & 2 & 50 & 100 \\
$\mathrm{Ni}$ & 0.4 & 10 & 40 \\
$\mathrm{~Pb}$ & 0.5 & 10 & 50 \\
$\mathrm{Zn}$ & 4 & 50 & 200 \\
\hline
\end{tabular}



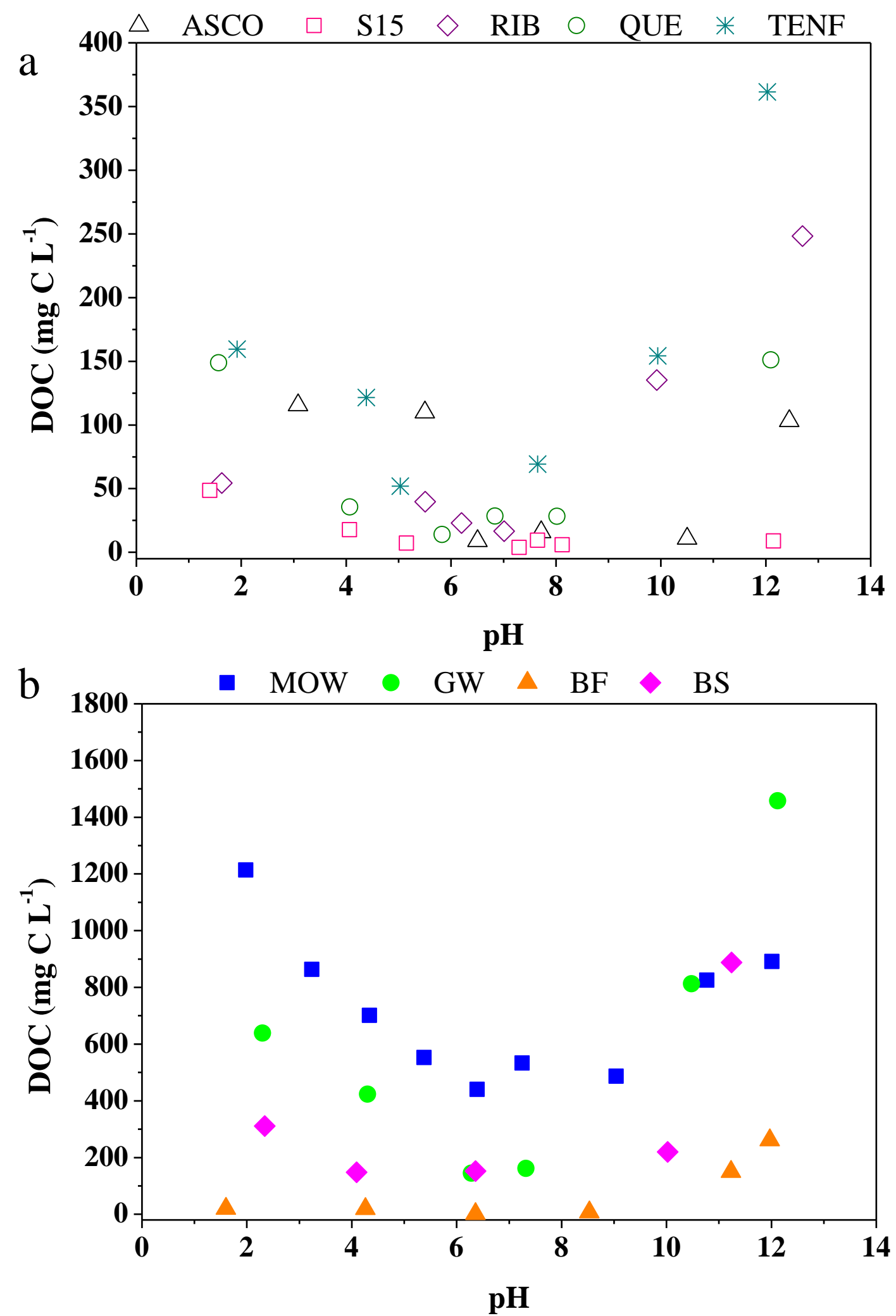

Fig. S1. $\mathrm{pH}_{\text {stat }}$ curves of DOC in a) untreated soils and b) amendments. 